\title{
MAMMALS
}

\section{RECORDS OF ALBERTA SMALL MAMMALS THROUGH ANALYSES OF GREAT HORNED OWL PELLETS}

\author{
D.B. (Tim) SCHOWALTER, Box 202, Delia, AB TOJ 0W0, LANCE ENGLEY,
} Alberta Conservation Association, 7th Floor, 6909-116th St. Edmonton, AB T6H 4P2, ROBIN DIGBY, Groundwork Natural Science, Box 516, East Coulee, AB T0J 1B0

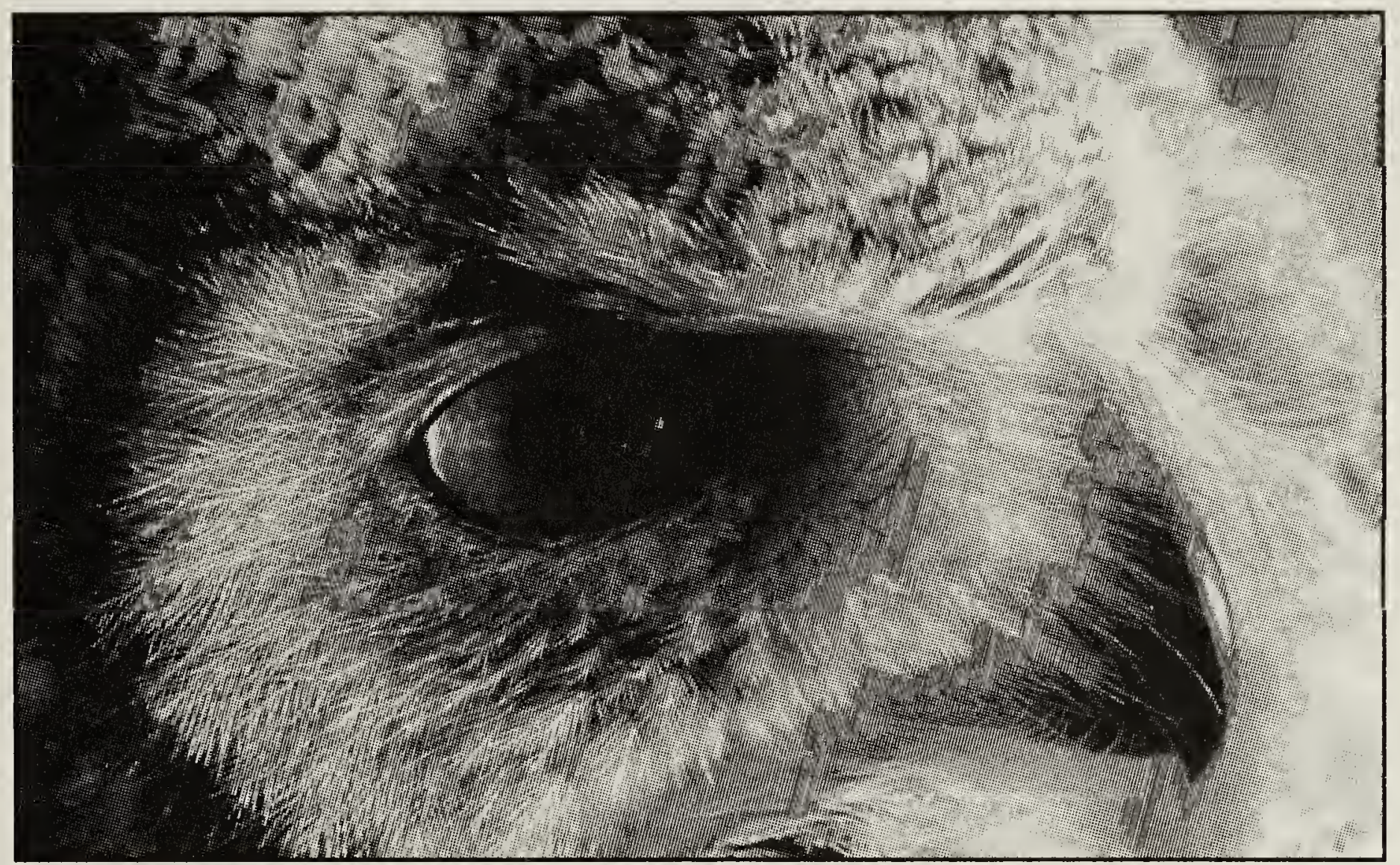

\section{Great Horned Owl}

Smith made extensive use of owl pellets for information on the distribution and relative abundance of small mammals in Alberta. ${ }^{10,11}$ He examined collections of pellets from the extreme southeastern portion of the province and Drumheller region in support of traditional trapping. While Deer Mice (Peromyscus maniculatus) made up the majority of the small mammals taken both by trapping and the owls, he found that owls capture numbers of some species, such as Sagebrush Voles (Lemmiscus curtatus) and Northern Grasshopper Mice (Onychyomys leucogaster) infrequently captured by museum and other researchers
Jean Harris

in those areas. Building on Smith's work, we previously examined mammal prey remains in Great Horned Owl pellets collected on the eastern grasslands and southern fringe of the parkland of Alberta. ${ }^{8,9}$ Like Smith, we found the prey to include considerable numbers of some species in locations where they were thought to be rare or absent.

Here we describe the results of analyses of Great Horned Owl pellets collected from 25 additional locations in Alberta (Table 1, Figure 1) between June 1999 and September 2000. Most pellets were collected in the western portion of the grasslands and in the 
parklands north and northwest of the previously sampled areas. As well, some collections were made in areas on the grasslands that had not been sampled previously.

We identified 4031 individual mammals of 29 species in the Great Horned Owl pellets. We found noteworthy distribution records of 11 species and the first occurrence of kangaroo rats in Great Horned Owl pellets from Alberta. As well as adding to the knowledge of small mammal distribution in Alberta, the information is of interest to wildlife managers, as five of the species found are classified as either being of potential conservation concern or "Status Undetermined" by Alberta Sustainable Resource Development.'

All of the pellets analyzed were collected in, or directly adjacent to, abandoned buildings. Great Horned Owls roost extensively in buildings, especially on the grasslands where concealed roosts in trees are limited. We frequently observed owls in buildings while looking for pellets and during other activities. The owls roost in buildings year round, though casual observation suggests that use is greatest in midsummer when newly fledged birds, frequently accompanied by an adult, are often encountered.

An important advantage of collecting pellets from buildings is that the pellets are protected from the weather and therefore accumulate over time. In virtually all cases, the owls probably cast the collected pellets over several years. As a result, the remains in the pellets represent an "average" of the prey taken by the owls at all seasons and, doubtless, reflect changes in abundance of prey species. Owl pellet analyses complement traditional research methods. Capture by researchers provides data on microhabitat occurrence, sex, age, weight, parasites, pelage characteristics and much other information not available from remains in pellets, but researchers seldom have the luxury of sampling small mammals at a location over long periods. A few of the collections described here were made in buildings that had been abandoned for over 20 years and some of the pellets collected were probably of similar age. Collections of pellets can be made quite easily. The pellets can be stored and analyzed at a later time. While the analysis of owl pellets is labour intensive, it is much less so than most other methods of sampling small mammals. As a result, pellets from a larger number of locations can be analyzed compared to the number of locations that can be sampled practically for small mammals directly by researchers.

Comparison of prey remains and systematic trapping around roost sites in Colorado suggests that Great Horned Owls take most of their prey near their roosts in prairie habitats in locations that have perches from which the owls can hunt. ${ }^{14}$ However, to our knowledge, systematic, year-round, study of the movements of Great Horned Owls in open habitats in Alberta has not been undertaken. It is possible that an owl ate an animal, then travelled some distance before casting a particular pellet. Therefore, new distribution records reported here which are based upon the occurrence of single animals in pellets should be considered provisional.

All identifications of prey remains were by TS. When necessary, identifications were confirmed by comparison to specimens in the University of Alberta Museum of Zoology (UAMZ). Voucher specimens were placed in that museum. The following species have new distribution records in Alberta based on pellet collections between June 1999 and September 2000.

\section{Arctic Shrew (Sorex arcticus)}

Arctic Shrews are expected to occur in moist environments over the treed portions of northern and central Alberta and along the foothills north from southwest of Calgary. The species is not known from the mountains or grasslands. ${ }^{12}$ The Arctic Shrew (UAMZ 10037) from an unused barn south 
Figure 1. Location of owl pellet collection sites.

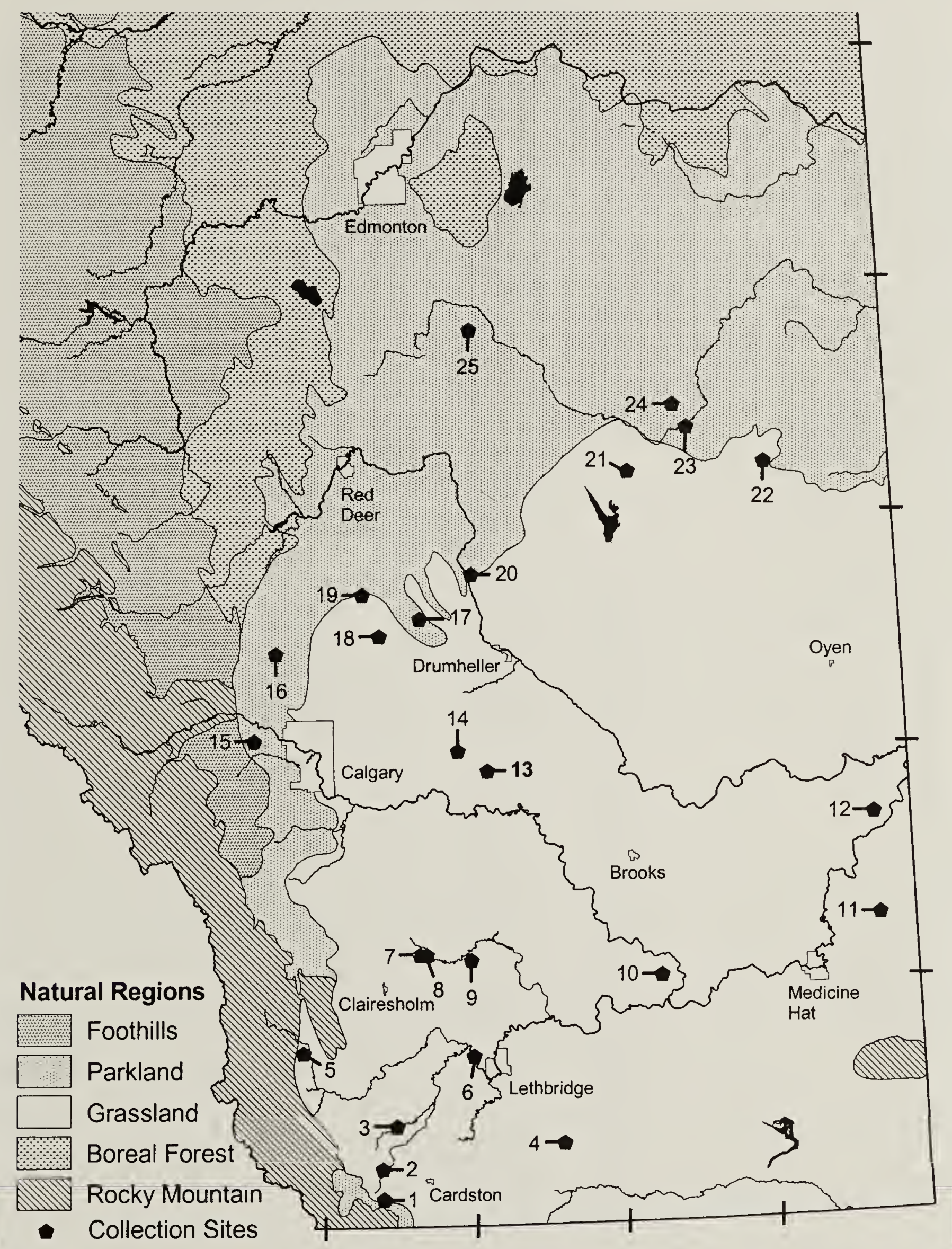

of Linden (Site 18) is in prairie habitat approximately $50 \mathrm{~km}$ east of the nearest records mapped by Smith. ${ }^{12}$ Currently, the location is quite dry; however the site overlooks a dry stream course with an abandoned beaver dam and patches of willows and aspen. If the specimen was not transported from a distant location, it may have been taken at a time when the local environment was moister.

Nuttall's (Mountain) Cottontail (Sylvilagus nuttalli)

Nuttall's Cottontail is a characteristic animal of prairie river valleys and coulees in Alberta. ${ }^{12}$ It is also widespread, though 
Species

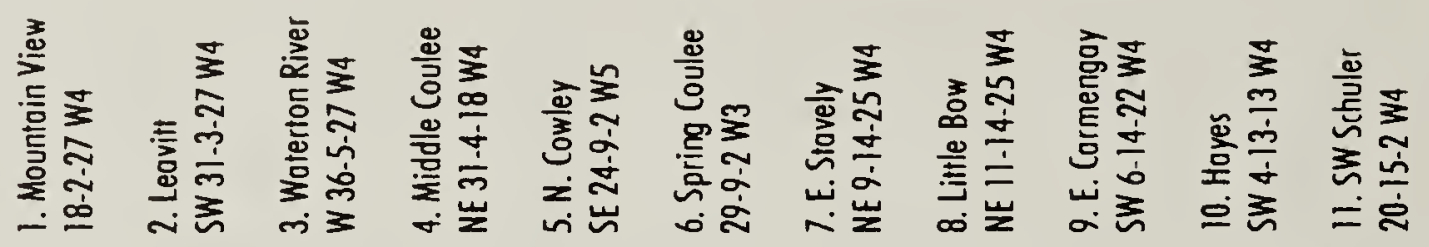

Common Shrew

Proirie Shrew

Proirie or Common Shrew

Dusky Shrew

Arctic Shrew*

Woter Shrew

Shrew species

Silver-hoired Bol

Myoris species

Bot species

Nuttoll's Cottontoil*

Wt.-toiled Jockrobbit

Snowshoe Hore

Richordson's Grd. Squirrel

Fronklin's Grd. Squirrel*

Northern Flying Squirrel*

Ord's Kongoroo Rot ${ }^{*}$

Olive-bckd Pocket Mouse*

Northern Pocket Gopher*

Deer Mouse

Nithn Grosshopper Mouse*

Meodow Vole

Southrn Red-backed Vole*

Long-toiled Vole*

Sagebrush Vole*

Prairie Vole*

Muskrot

Western Jumping Mouse

Jumping mouse species

House Mouse

Leost Weosel

Long-toiled Weosel

Striped Skunk

Totol Mommols

- $\sim$

出岕客

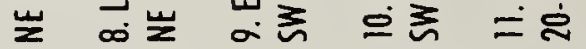




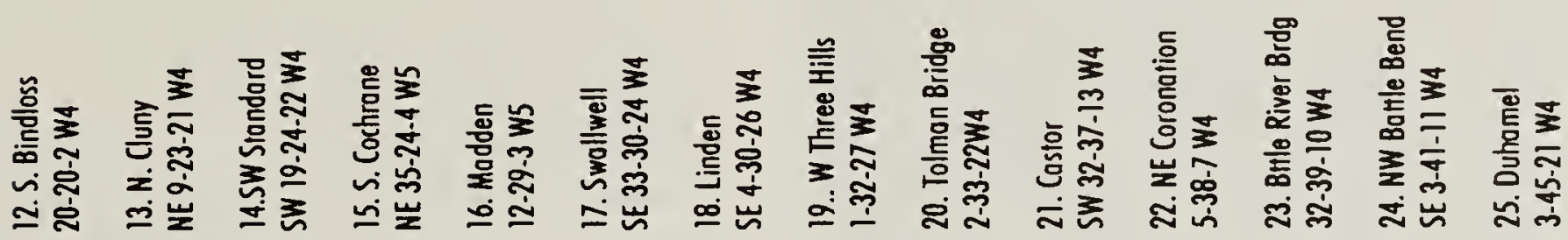

\begin{tabular}{|c|c|c|c|c|c|c|c|c|c|c|c|c|c|}
\hline & & & & 4 & & & 3 & & & & & & \\
\hline 1 & 1 & & & & & & 5 & 1 & & & & & 1 \\
\hline & & & & & & 2 & 3 & & & & & & \\
\hline & & & & & & & 1 & 1 & & & 1 & & \\
\hline & & & & & & 1 & 1 & & & & & & \\
\hline & & & & 1 & & & & & & & & & \\
\hline & & & & & & & & & & & 3 & & 1 \\
\hline & & & & & & & & & & & & & \\
\hline & & & & & & & & 1 & & & & & \\
\hline & & & & & & & & 1 & & & & & \\
\hline & 3 & & & & & & & 1 & & & & & \\
\hline & 1 & & & & & & & & & & & & \\
\hline & & & & & & 1 & 1 & & & & 1 & & \\
\hline & 2 & 5 & & 3 & & & 2 & & 3 & 1 & & & \\
\hline & & & & & & & & & 1 & & & & \\
\hline & & & & & & & & & & & 3 & & \\
\hline 7 & & & & & & & & & 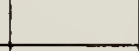 & & & & \\
\hline 7 & & & & & & & & & & & & & \\
\hline 50 & & & 1 & 29 & & 4 & & 1 & 1 & 5 & 5 & 6 & 10 \\
\hline 33 & 195 & 190 & 4 & 130 & 16 & 20 & 178 & 68 & 3 & 8 & 31 & 7 & 5 \\
\hline 9 & 5 & 7 & & & & 2 & & & 3 & 2 & 1 & 1 & \\
\hline 10 & 22 & 28 & 1 & 49 & 2 & 7 & 79 & 11 & 2 & 3 & 66 & 2 & 5 \\
\hline & & & & & & & 12 & 1 & & 1 & 16 & 2 & 2 \\
\hline & & & & 2 & & & & & & & & & \\
\hline 5 & 15 & 1 & & & & & & & & 6 & & & \\
\hline & & & 1 & 23 & & & 20 & & 1 & 2 & & & 1 \\
\hline & 1 & & & 1 & & 1 & 2 & & & & & & \\
\hline & 4 & 1 & & & & & & & & & & & \\
\hline & & & & & & & 1 & 1 & & & & & 1 \\
\hline & 1 & 7 & & 7 & & 2 & & & & & & & 2 \\
\hline & & & & 1 & & & 2 & & & & & & \\
\hline & 1 & & & & & & & & & & & & \\
\hline 122 & 25 & 240 & 7 & 250 & 18 & 40 & 332 & 87 & 14 & 28 & 129 & 18 & 28 \\
\hline
\end{tabular}

\begin{tabular}{|r|r|r|r|r|r|r|r|r|r|r|r|r|r|}
\hline & 16 & 10 & 2 & 9 & & 14 & & 78 & 3 & & 7 & 1 & \\
\hline & 1 & & & 1 & & 6 & & & & & & & \\
\hline & 6 & 1 & & & & 2 & & & & & 6 & 1 & \\
\hline & 2 & & & & & & & & & & & & \\
\hline & 1 & & 4 & 1 & 1 & & 1 & & & 8 & & \\
\hline & & & & & & & & & & & & & \\
\hline & & & & & & & & 1 & & & & & \\
\hline & & & & 1 & & & & & & & 4 & & 1 \\
\hline & & & 1 & & & 6 & 76 & & & 5 & & 2 \\
\hline & 2 & & & 3 & 4 & 1 & 11 & 9 & 2 & & 7 & 2 & 40 \\
\hline
\end{tabular}




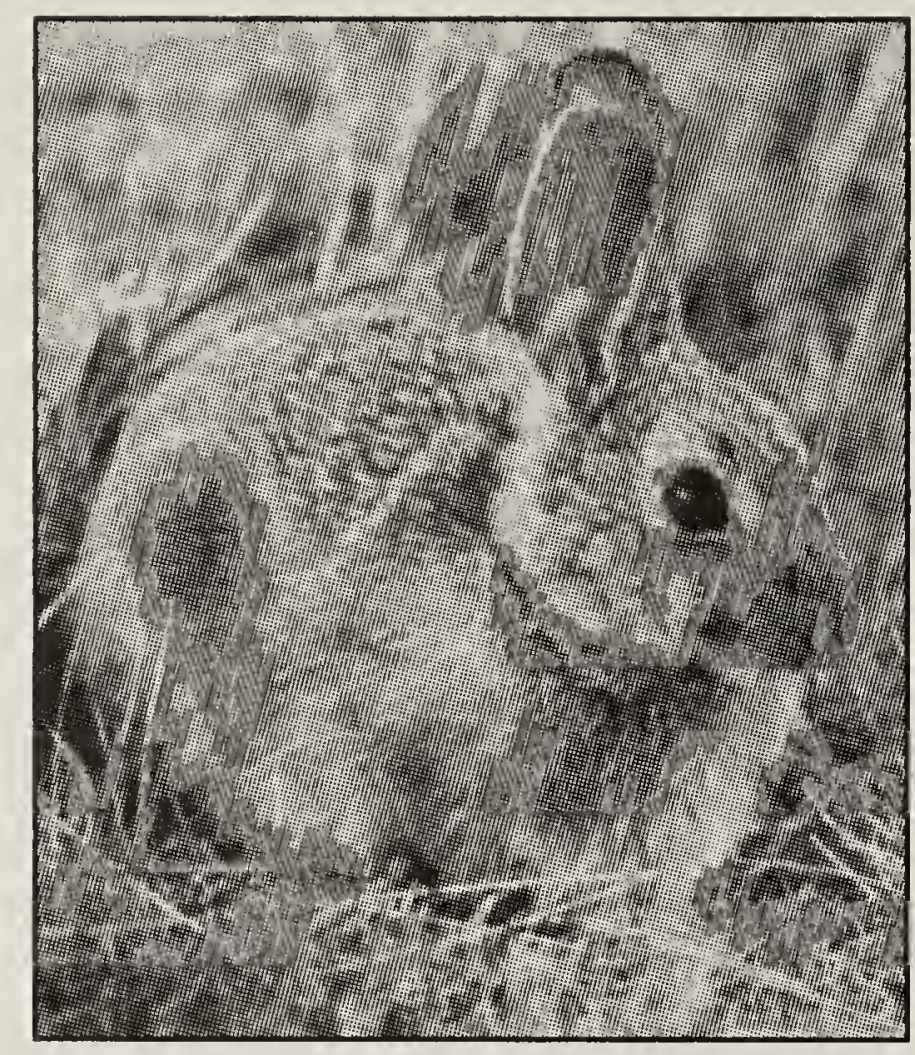

Nuttall's Cottontail

Andrius Valadke

less conspicuous, in locations offering some cover away from the valleys and coulees. ${ }^{9} .11$ The Nuttall's Cottontail (UAMZ 10100) from along the Waterton River (Site 3 ) is approximately $50 \mathrm{~km}$ northwest of the nearest records reported by Smith (1993) and is the first occurrence from along that river. Treed areas and considerable brush around the site near the river are suitable habitat for this species improving the possibility that additional confirmatory records in the area can be found.

\section{Franklin's Ground Squirrel (Spermophilus franklinii)}

Franklin's Ground Squirrels are expected throughout the parkland of Alberta except in the southwest portion of that natural region. ${ }^{2}$ Occurrences of the species are of note as it is currently classified as being of "Undetermined" status in Alberta. " An aggregation of the squirrels lives around an abandoned grain bin partially filled with oats near Castor (Site 21). A Great Horned Owl resident in the upper part of the building had taken at least two of the squirrels, one of which was found partially eaten (Figure 2). Franklin's Ground Squirrel bones from a fresh pellet, which very likely represents portions of the partially eaten ground squirrel, have been placed in the University of Alberta Museum of Zoology (UAMZ 10032). The site is approximately $30 \mathrm{~km}$ south of previous records., ${ }^{2,12}$

While there are no specimen records, Franklin's Ground Squirrels have been seen in the Byemoor area, 35 to $40 \mathrm{~km}$ southwest of the Castor location, since at least the The

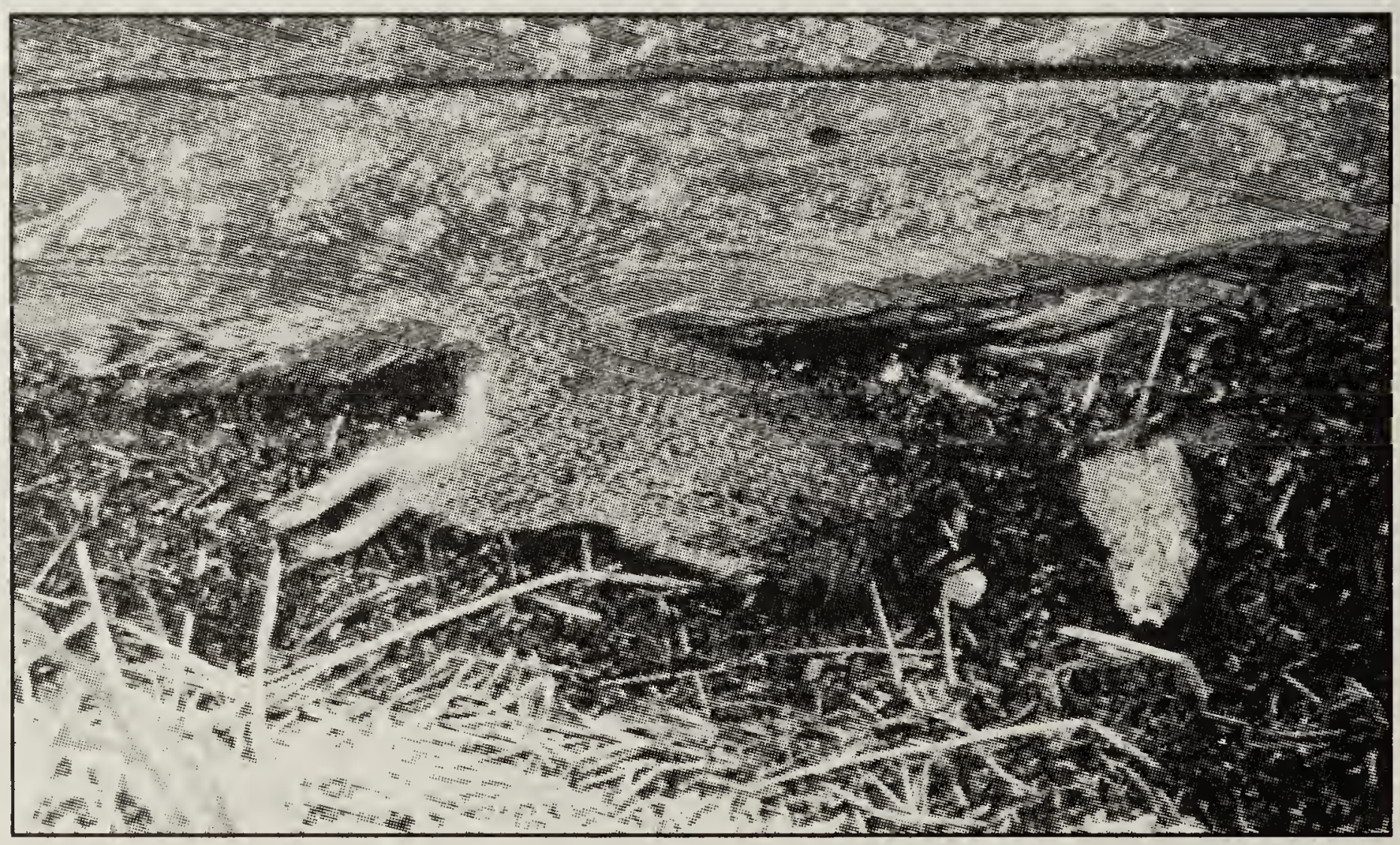

Figure 2. Partially eaten Franklin's Ground Squirrel and fresh Great Horned Owl Pellet that contains parts of the ground squirrel. 
1940s (Joel Nicholson, pers. comm.). Additionally, one of us (TS) has seen roadkilled Franklin's Ground Squirrels south of Byemoor and near Endiang to the east. Rancher Dan Chostner (pers. comm.) has also seen Franklin's Ground Squirrels in the Endiang area.

It is interesting that residents of the Byemoor area are quite familiar with an animal of uncertain status in Alberta. Their observations point out the value of local knowledge in establishing the distribution of some species.

\section{Northern Flying Squirrel (Glaucomys sabrinus)}

The Northern Flying Squirrel remains at Battle River Bridge (UAMZ 10001, Site 23) support an earlier owl pellet distribution record for the species in the area. ${ }^{8}$

\section{Olive-backed Pocket Mouse (Perognathus fasciatus)}

Olive-backed Pocket Mice are ranked as "Sensitive" in Alberta." Occurrences are therefore of some interest. The species appears to be confined to the southeastern portion of Alberta. ${ }^{2}$ An Olive-backed Pocket Mouse (UAMZ 10016) was recovered from a large sample of mice and voles at Middle Coulee (Site 4) southeast of Lethbridge. Smith ${ }^{12}$ does not record this species from the region; however, he does note an owl pellet record in the region. ${ }^{10}$ The records reported here are approximately $40 \mathrm{~km}$ west of previous records (Figure 3 ).

\section{Ord's Kangaroo Rat (Dipodomys ordii)}

In Alberta, Ord's Kangaroo Rat is limited to the sand hills region near the Saskatchewan border south of the Red Deer River. ${ }^{4}$ Within that area, it appears to be relatively common. ${ }^{4,6}$ The species is ranked as "May be at Risk." Seven specimens of Ord's Kangaroo Rat were found in pellets from south of Bindloss (Site 12) on the northern edge of the Middle Sandhills. While a single sample of seven specimens is inadequate to allow conclusions to be drawn, the results suggest that Great Horned Owls might be non-trivial predators of this species.

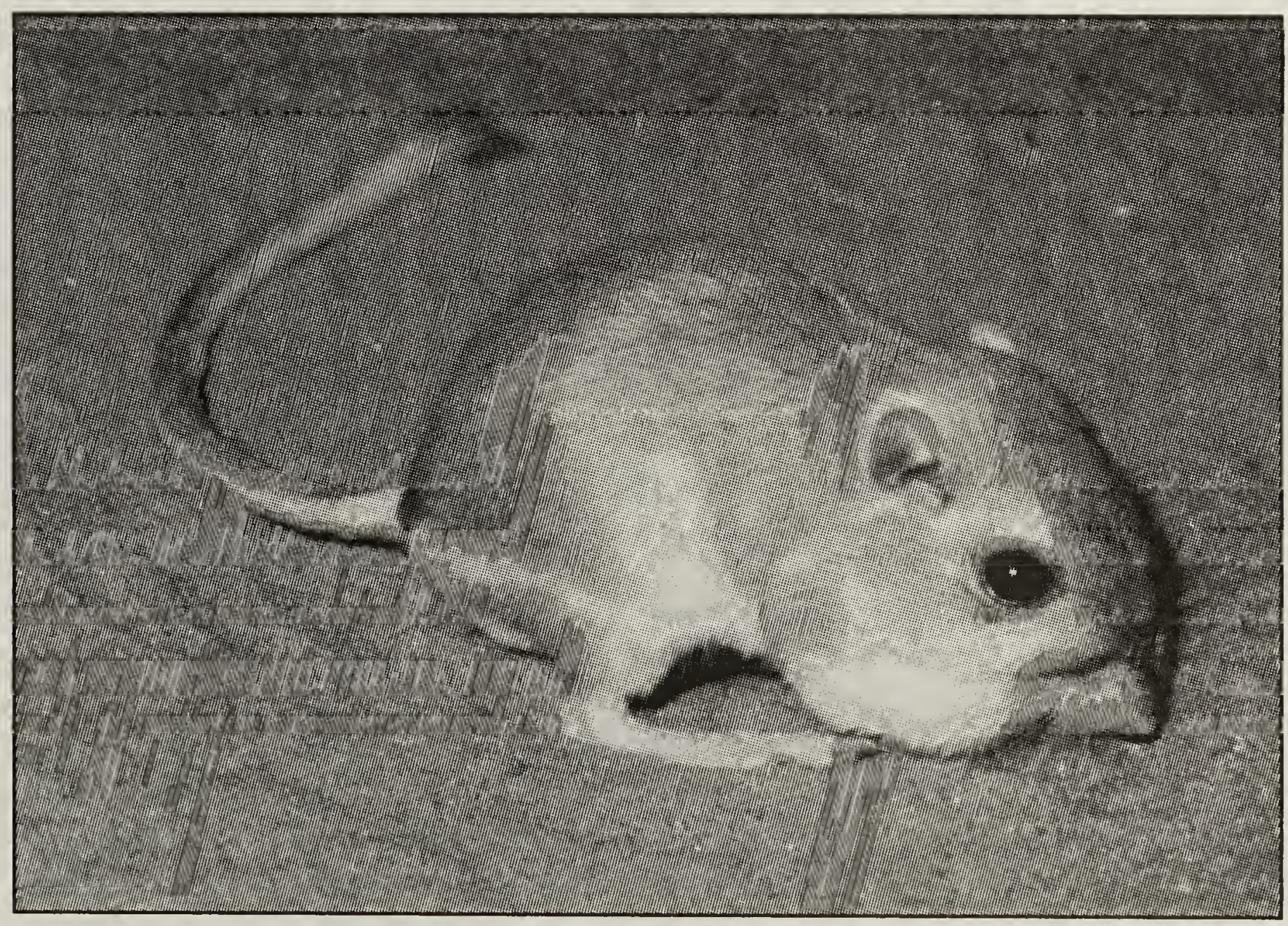



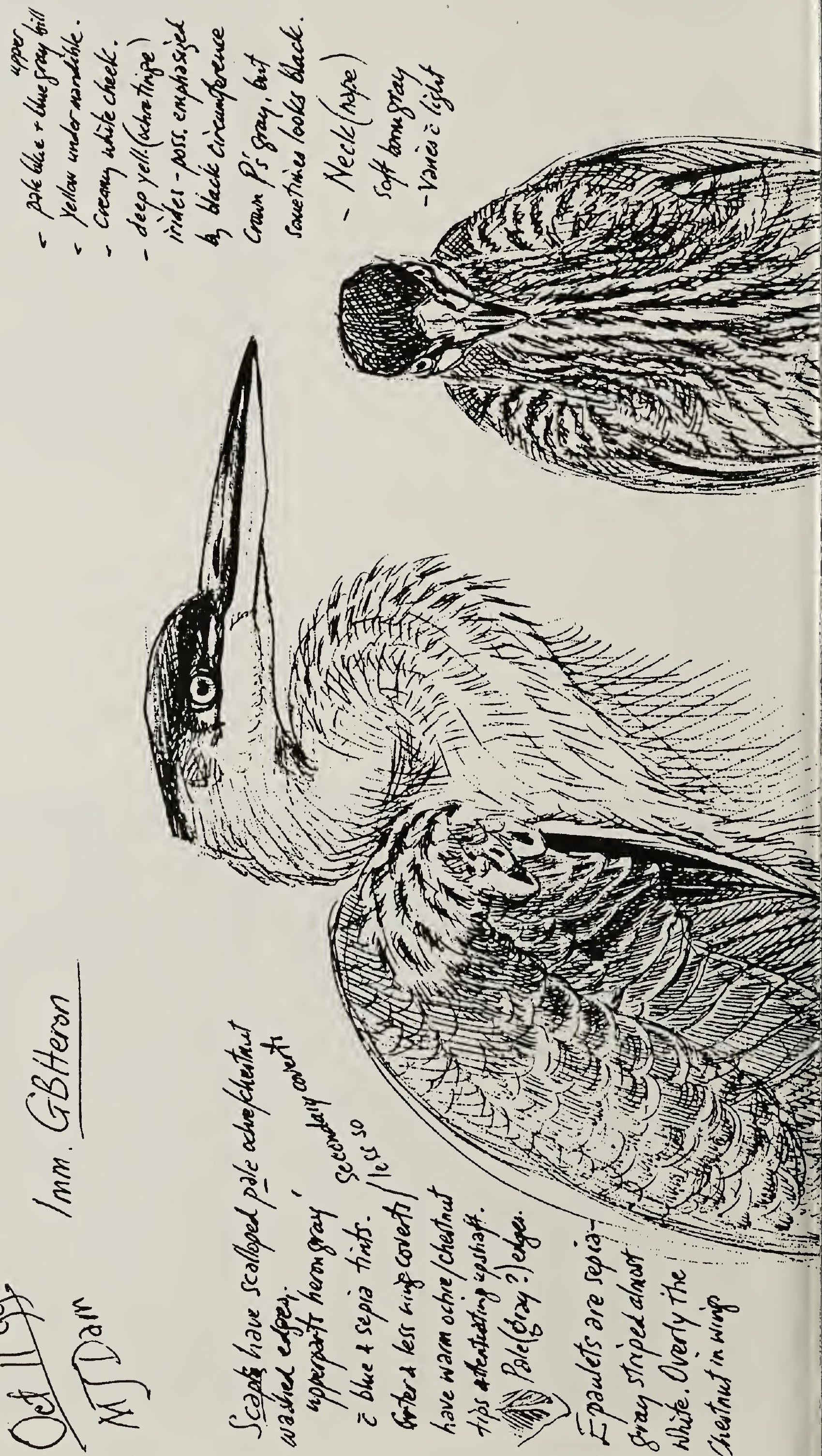


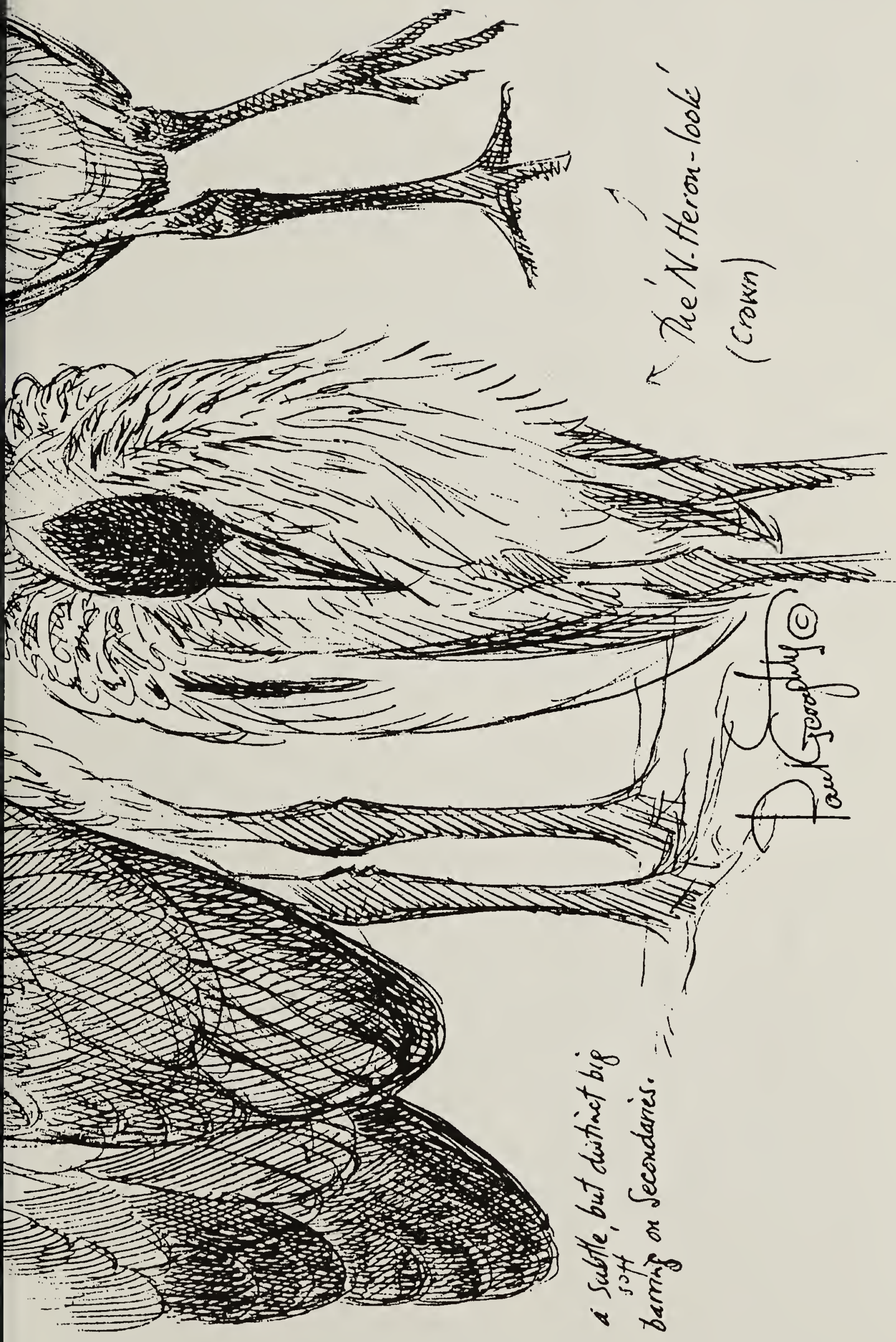


Figure 3. Locations of museum and Great Horned Owl pellet specimens of Olivebacked Pocket Mice in Alberta. SQUARES = sites described in the curent study, CIRCLES = previously published GHOW pellet sites ${ }^{7 \cdot 11}$, STARS = previously published BUOW pellet sites ${ }^{10,11}$, CROSSES $=$ museum specimens ${ }^{2}$

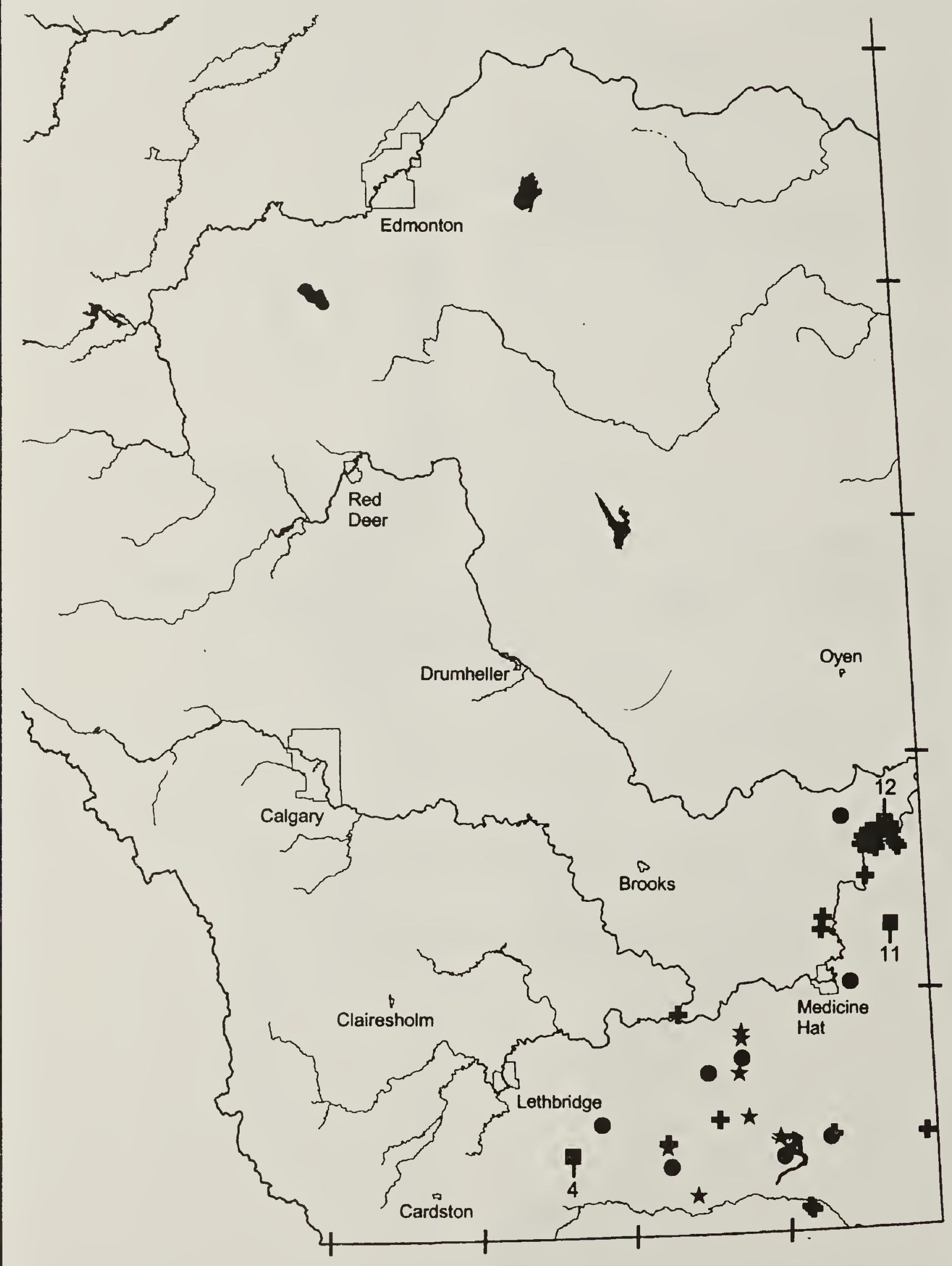


specimens were donated to the Provincial Museum of Alberta for ongoing research (David Gummer, pers. comm.).

\section{Northern Pocket Gopher (Thomomys talpoides)}

Northern Pocket Gophers are not known to occur over much of southern Alberta. ${ }^{12}$ However, Northern Pocket Gopher populations have increased rapidly and probably have spread in that part of the province (Bryan Phillips, pers. comm.). The extent of their current distribution has not been adequately mapped. The record from northwest of Leavitt (Site 2) is approximately $20 \mathrm{~km}$ east of previous records. ${ }^{12}$ However, Northern Pocket Gophers are reported as pests in alfalfa fields northwest of Warner and in the area of Taber (Jammie Meeks and Dick Layton, pers. comm.). The latter region is approximately $85 \mathrm{~km}$ from records to the east and $50 \mathrm{~km}$ east of an apparently isolated record at Lethbridge. ${ }^{12}$ It is not known if these reports reflect long distance spread of Northern Pocket Gophers populations or if the animals existed in the area in low numbers previously and were not recorded.

\section{Northern Grasshopper Mouse (Onychomys leucogaster)}

Over a considerable portion of their range in central and southern Alberta, Northern Grasshopper Mice are known only from owl pellet records (Figure 4). The specimens from Linden (UAMZ 10036, Site 18) add to the previously known distribution and are 55 to $60 \mathrm{~km}$ from previous owl pellet records to the northeast, east, and southeast.9,10 Pellet analyses suggest that Great Horned Owls are highly successful in capturing Northern Grasshopper Mice. The lack of Northern Grasshopper Mice in sizable pellet collections from Leavitt (Site 2), Madden (Site 16), and north of Cowley (Site 5) on western portion of the grasslands of Alberta is therefore of interest.

The occurrence of 88 Northern Grasshopper Mice in the sample from east of Stavely (Site 7) is remarkable as there are only 33 non-owl pellet specimens of Northern Grasshopper Mice from Alberta in museum collections. ${ }^{2}$ Reasons for such a large number of the species in pellets on the apparent edge of its range are not known. The Stavely site is an area of extremely sandy soil, some of which has been planted to tame grass. Large numbers of Northern Grasshopper Mice have also been found in other owl pellet samples collected from sandy locations, ${ }^{89}$ including from east of Carmenay (Site 9). However, the animals also occur frequently in pellet collections from areas that are not particularly sandy such as Middle Coulee (Site 4), Little Bow (Site 8), and southwest of Schuler (Site 11).

\section{Southern Red-backed Vole (Clethrionomys gapperi)}

The recovery of a Southern Red-backed Vole (UAMZ 10003) from a prairie location southwest of Schuler (Site 11) was unexpected as it is about $125 \mathrm{~km}$ south of previous Alberta records and $65 \mathrm{~km}$ north of records in the Cypress Hills. ${ }^{12}$ As Southern Red-backed Voles are not thought to occur on the grasslands of Alberta, the specimen may have been transported some distance to the location by the owl. However, two Southern Red-backed Voles were captured in the Great Sand Hills of Saskatchewan to the east of this location. ${ }^{3}$

\section{Long-tailed Vole (Microtus longicaudus)}

Long-tailed Voles occur in the mountains and foothills of Alberta. A small number of scattered captures have also been made on the grasslands along the Milk River and south of the Cypress Hills. ${ }^{2}$ Separation of Long-tailed Voles and the common Meadow Vole solely on the basis of teeth is not absolutely certain as there is overlap in the dental characteristics. ${ }^{13}$ Long-tailed Voles were provisionally identified from pellets from northwest of Leavitt (UAMZ 10012, Site 2) and near Madden (UAMZ 10007, Site 16) on the basis of dental characters. The specimen from Madden is approximately $64 \mathrm{~km}$ northeast of the nearest record mapped by Smith. ${ }^{12}$ Given the 
Figure 4. Locations of museum and Great Horned Owl pellet specimens of Northern Grasshopper Mice in Alberta. SQUARES = sites described in the curent study, CIRCLES = previously published GHOW pellet sites ${ }^{7-11}$, STARS = previously published BUOW pellet sites ${ }^{10,11}$, CROSSES $=$ museum specimens ${ }^{2}$

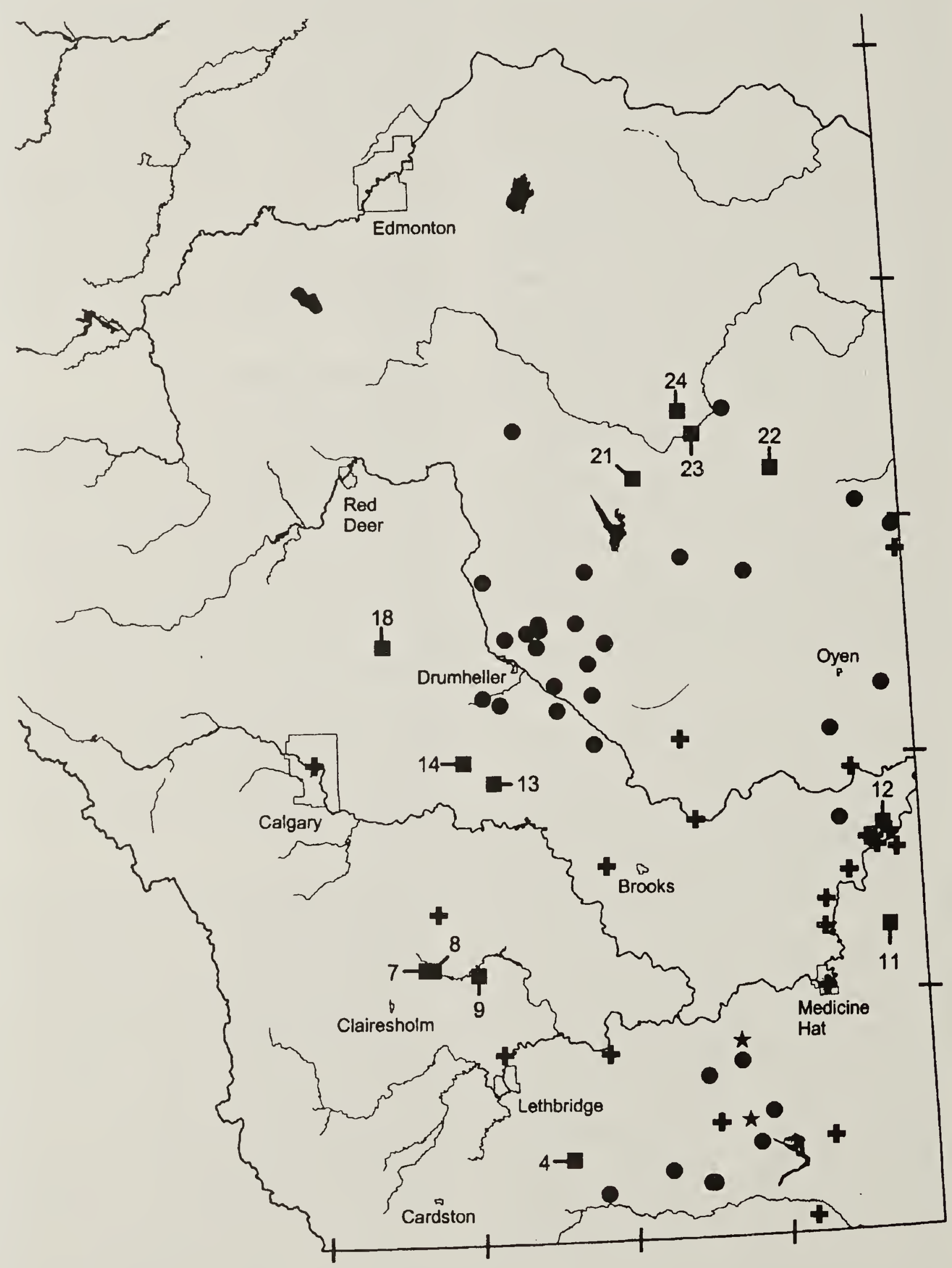


sporadic nature of occurrence of Long-tailed Voles outside the mountains, ${ }^{12}$ new distribution records would not be unexpected. However, the uncertainty of identification using teeth and possibility of long-distance transport by the owls necessitates the gathering of additional evidence to establish the occurrence of the species at the locations reported here.

\section{Sagebrush Vole (Lemmiscus curtatus)}

Sagebrush Voles occur widely on the grasslands of Alberta (Figure 5) and are abundant in many owl pellet collections (Table 1). ${ }^{8,9,10,11}$ Specimens from Leavitt (UAMZ 10014, Site 2) and Mountain View (UAMZ 10008, Site 1) are approximately $20 \mathrm{~km}$ west of the nearest previous record. 12 The six specimens from northeast of Coronation (UAMZ 10028, Site 22) are approximately $48 \mathrm{~km}$ north of the nearest previously described location for the species. ${ }^{8}$ Of interest is that Prairie Voles also occur at the Coronation site (Table 1); the co-occurrence of Sagebrush Voles and Prairie Voles in owl pellets has not been previously reported in Alberta despite an examination of a number of collections from sites with open parkland similar to that of the Coronation site.

\section{Prairie Vole (Microtus ochrogaster)}

Prairie Voles are ranked as "Undetermined" in Alberta.' and are one of the least frequently captured small mammals in the province. ${ }^{2}$ While Prairie Voles have been found in some samples of owl pellets in the past, ${ }^{8,9}$ some of the records reported here are of larger numbers of individuals. We recovered Prairie Voles south of Cochrane (UAMZ 100010, Site 15), northwest of Madden (UAMZ 100017 , Site 16), west of Three Hills (UAMZ 10005, Site 19), near Castor (UAMZ 100021 , Site 21), northeast of Coronation (UAMZ 10031, Site 22) and near Duhamel (UAMZ 10033, Site 25). Some of these locations are new marginal records for the species (Figure 6). Of note, the record at Cochrane (Site 15) is approximately $67 \mathrm{~km}$ south of a previously mapped record 2,12 though the specimens we found at Madden (Site 16) are between the Cochrane location and the previous record. The records at Castor and Coronation are approximately $60 \mathrm{~km}$ southwest and $35 \mathrm{~km}$ southeast, respectively, of a previous record. ${ }^{12}$

The occurrence of 23 individuals in the Madden sample (Table 1) and the number of new location records suggests that further examination of owl pellets will produce information of value in helping to determine the distribution and status of Prairie Voles in Alberta.

\section{Summary}

In this study, new distribution records of 11 species of Alberta mammals and observations of a twelfth are reported. Several of those species have been identified as being of conservation concern.' These, and previous results, ${ }^{8,9,10,11}$ suggest that analyses of additional pellets, particularly from areas not previously sampled, will continue to provide new information on the occurrence of small mammal species in Alberta

\section{Acknowledgements}

Many the results described here were obtained through research contracts with Alberta Sustainable Resource Development to TS. ${ }^{7}$ Gordon Court supervised the contracts and actively encouraged the research. His interest and support are gratefully acknowledged. Sorting of some owl pellets was done by participants at the Dinosaur Country Science Camp under supervision of RD. The enthusiasm of the camp counsellors Matt Shannon and Stu Crawford and camp participants has been an important dimension of the work. Wayne Roberts (University of Alberta Museum of Zoology) generously provided ready access to the collections in his care so that identifications of the mammals could be confirmed. Wayne further accepted voucher specimens. We extend our thanks to Dan Chostner, Dick Layton (Municipal District 
Figure 5. Locations of museum and Great Horned Owl pellet specimens of Sagebrush Vole in Alberta. SQUARES = sites described in the curent study, CIRCLES = previously published GHOW pellet sites ${ }^{7-11}$, STARS = previously published BUOW pellet sites ${ }^{10,11}$, CROSSES $=$ museum specimens $^{2}$

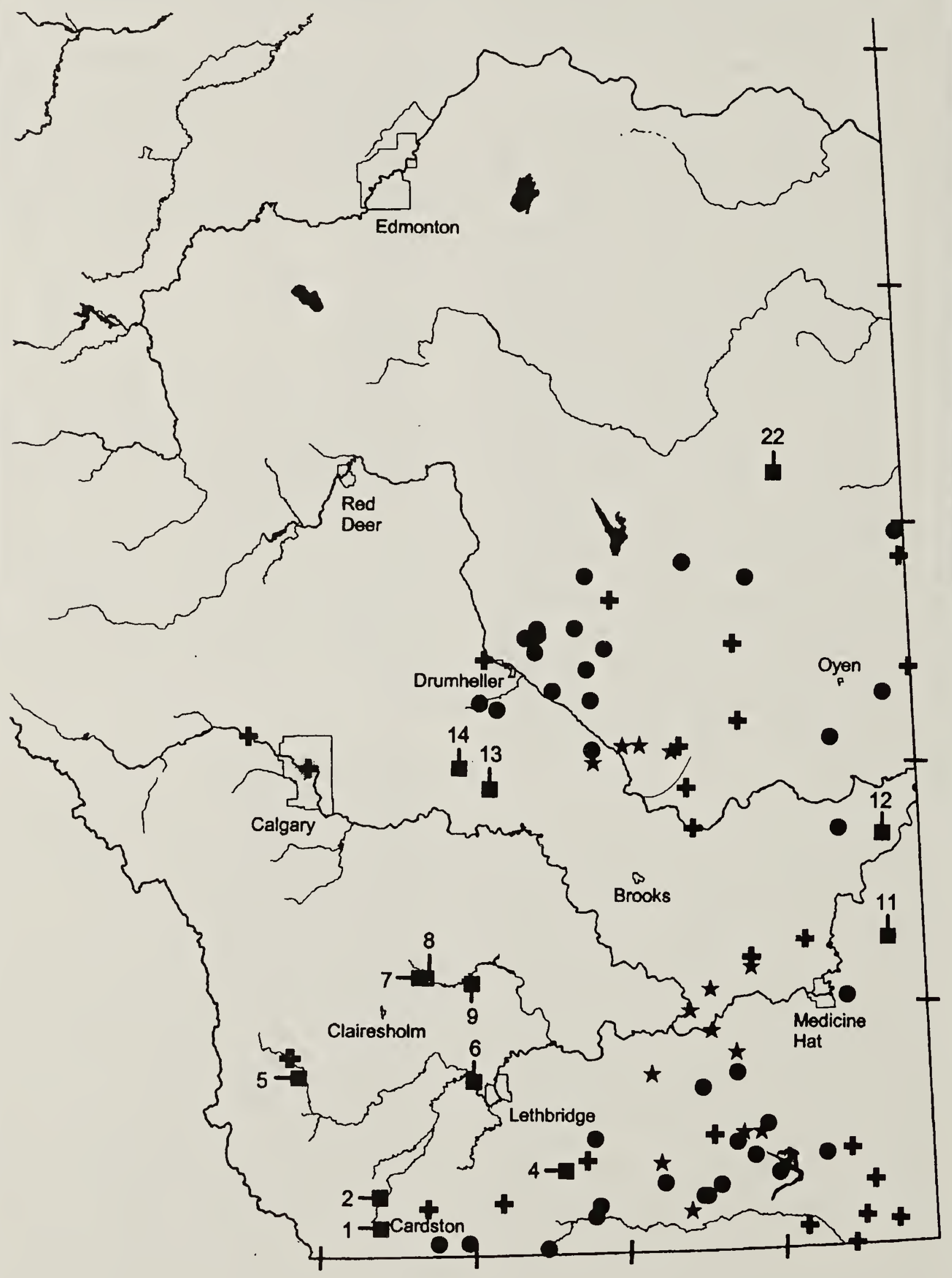


Figure 6. Locations of museum and Great Horned Owl pellet specimens of Prairie Vole in Alberta. SQUARES = sites described in the curent study, CIRCLES = previously published GHOW pellet sites ${ }^{7 \cdot 11}$, STARS = previously published BUOW pellet sites ${ }^{10,11}$, CROSSES $=$ museum specimens ${ }^{2}$

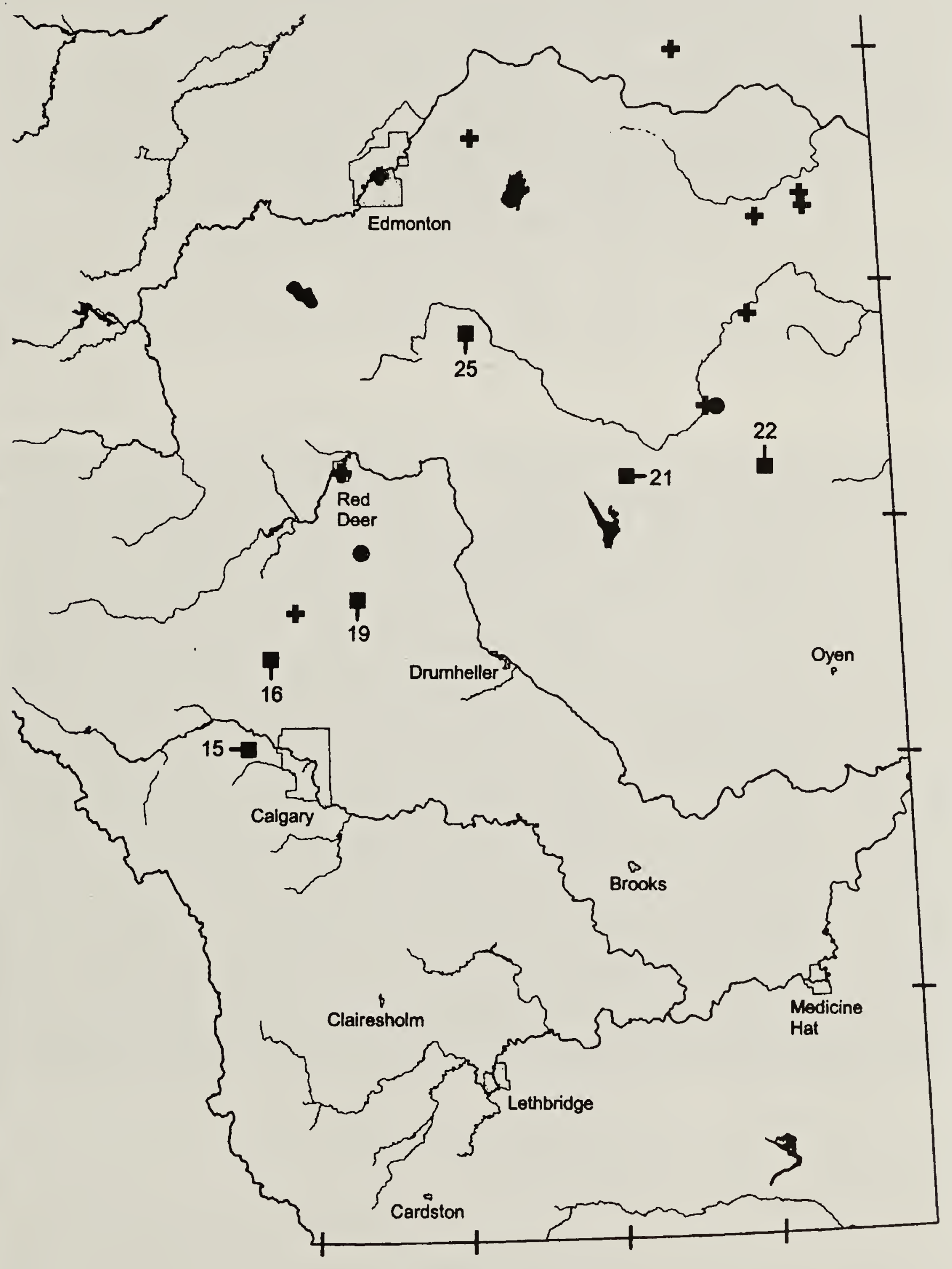


of Taber), Jamie Meeks (County of Warner), Joel Nicholson (Alberta Sustainable Resource Development, Medicine Hat), and Bryan Phillips (Municipal District of Cardston) for sharing their personal observations and knowledge. The anonymous reviewer provided insightful comments and alerted us to the published occurrence of red-backed voles in the Great Sand Hills of Saskatchewan. Finally, special thanks are due to the landowners who gave permission to collect pellets on their land.

\section{ALBERTA SUSTAINABLE RE-} SOURCE DEVELOPMENT. 2001. The General Status of Alberta Wild Species 2000. Alberta Sustainable Resource Development, Fish and Wildlife Service, Edmonton, AB. 46pp.

2. ENGLEY, L. and M. NORTON. 2001. Distribution of Selected Small Mammals in Alberta. Alberta Sustainable Resource Development, Fish and Wildlife Service, Alberta Species at Risk Report No. 12. Edmonton, AB. 75pp.

3. EPP, H.T., and D.B. WALKER. 1980. Terrestrial vertebrate fauna of the Great Sand Hills, In: Epp, H.T., and L. TownleySmith. (eds.) The Great Sand Hills of Saskatchewan: a Report Prepared for the Saskatchewan Department of the Environment on the Ecology and Archaeology and on Resource Management and Land Use in the Great Sand Hills of Saskatchewan. Saskatchewan Department of the Environment, Regina.

4. GUMMER, D.L. 1997. Ord's Kangaroo Rat (Dipodomys ordii). Alberta Environmental Protection, Wildlife Management Division, Wildlife Status Report No. 4, Edmonton, AB. 16pp.

5. LUISELLI, L. and D. CAPIZZI, 1996. Composition of a small mammal community studied by three comparative methods. Acta Theriologica 41:425-431.
6. REYNOLDS, H.W., S.J. BARRY and H.P.L. KILIAAN: 1999. Small mammal component report: Canadian Forces Bases Suffield National Wildlife Area. Canadian Wildlife Service, Edmonton, AB. 140pp.

7. SCHOWALTER, D. 2001. Distribution and abundance of small mammals of the western plains of Alberta as determined from great horned owl pellets. Alberta Environmental Protection, Wildlife Management Division, Wildlife Status Report No. 17, Edmonton, AB.

8. SCHOWALTER, D. and R. DIGBY. 1997. Distribution records of small mammals from east-central Alberta from Great Horned Owl Pellets. Alberta Naturalist 27: 32-36.

9. SCHOWALTER, D. and R. DIGBY. 1999. New distribution records of small mammals from Alberta from Great Horned Owl pellets. Alberta Naturalist 29: 82-83.

10. SMITH, H.C. 1981. The distribution of mammals in southeastern Alberta as indicated by the analysis of owl pellets. Blue Jay 39: 230-238.

11. SMITH, H.C. 1992. Mammals of the Drumheller Area. Provincial Museum of Alberta Nat. Hist. Occ. Pap. No. 17, Edmonton, AB. 25pp.

12. SMITH, H.C. 1993. Alberta Mammals: An Atlas and Guide. The Provincial Museum of Alberta, Edmonton, AB. 238pp.

13. SMOLEN, M.J., and B.L. KELLER. 1987. Microtus longicaudus. Mammalian Species No. 271. American Society of Mammalogists.

14. ZIMMERMAN, G., P. STAPP, and B. VAN HORNE 1996. Seasonal variation in the diet of great horned owls (Bubo virginianus) on shortgrass prairie. American Midland Naturalist 136: 149-156. 

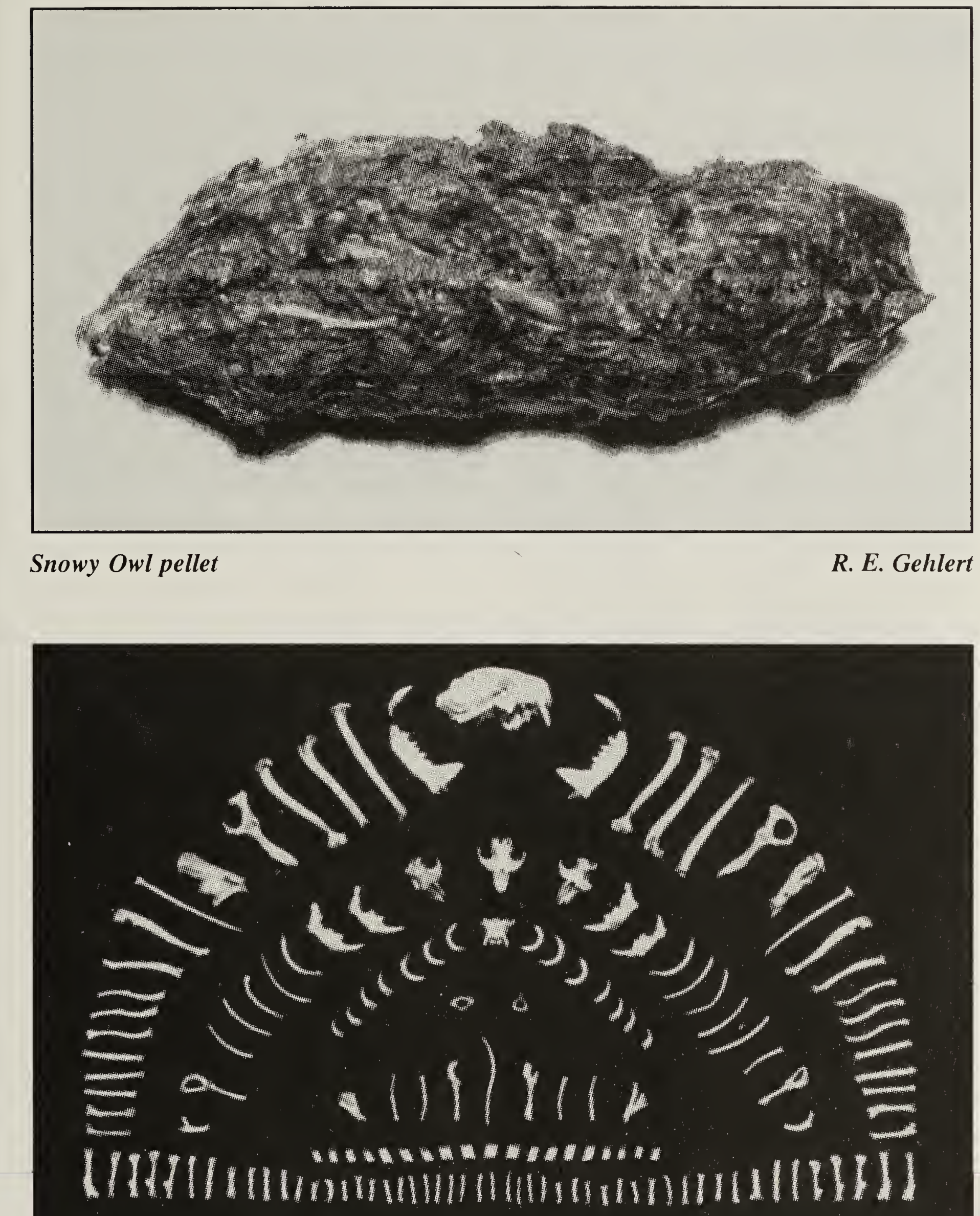

The contents of the Snowy Owl pellet shown above, which included one short-tailed weasel and a inimum of four meadow voles (Microtus sp.)

E. Gehlert

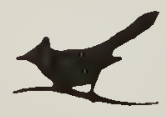

